\title{
Assessing the Hydrological Conditions of the Usangu Wetlands in Tanzania
}

\author{
Shadrack Mwakalila \\ Department of Geography, University of Dar-es-Salaam, Dar es Salaam, Tanzania \\ E-mail: smwakalila@yahoo.com \\ Received September 21, 2011; revised October 25, 2011; accepted November 27, 2011
}

\begin{abstract}
Although wetlands make up less than $10 \%$ of Tanzania, their "critical, life support, ecosystem services" sustain over 95\% of lives, of wildlife and of livestock. They provide security as sources of food, water, energy, economy and livelihoods, therefore, the aim of this paper is to address the current hydrologic conditions of Usangu wetlands. Several approaches were used in the collection of data for analysis. Both primary and secondary data was collected and analysed. The key finding shows that, the overall area of the Usangu Wetlands is divided into two main portions, the Eastern Wetland and the Western Wetland, the core wetland, the Ihefu Swamp varies between 30 and $65 \mathrm{~km}^{2}$, whereas the seasonally wetted areas varies between 260 and 1800 $\mathrm{km}^{2}$. Major perennial rivers which feed the Ihefu swamp in Usangu wetlands include Kimani, Mbalali, Ndembera and the Great Ruaha River. The contribution from Mbalali River ranges between 69.17\% and 47.78\%; from Ndembera River ranges between 25\% and 13.83\%; from Kimani River ranges between 25\% and $8.33 \%$ and from Great Ruaha River contribution ranges $24.0 \%$ and $2.96 \%$. The irrigated agriculture is most important as a user of water and impacts most heavily on wetlands. Abstraction of water for agriculture is leading to dried up rivers, falling ground water tables, salinated soil and polluted waterways.
\end{abstract}

Keywords: River Flows, Usangu Wetlands, Irrigation, Great Ruaha River

\section{Introduction}

As natural ecosystems, wetlands are an essential part of the ecology and like any other resources they provide social and economic benefits to human life, whether directly or indirectly. These benefits include among others irrigation agriculture, fishing, water supply, timber production, transport, recreation, tourism, papyrus, sediment/ toxicant retention, flood control, groundwater recharge and discharge [1-3]. Wetlands also serve as refugia for threatened indigenous fish species [4]. There is currently a growing appreciation of the natural functions of wetlands, and the values and different forms of uses that humans attach to them. Wise use and special conservation strategies are therefore needed in order to sustain their productivity.

For years, wetlands have been considered wastelands, unsustainably managed, taken for granted, unappreciated, undervalued, severely encroached and over-abstracted, especially by agriculture and in particular, for irrigation. Today, we realize that although wetlands make up less than $10 \%$ of Tanzania, their "critical, life support ser- vices” sustain over $95 \%$ of our lives, our crops, our wildlife and our livestock. They provide security to $80 \%$ of society, the rural poor, as sources of food, water, economy and livelihoods. However, they are fragile, the most vulnerable ecosystem, sensitive and susceptible to climate change as well as to over-use, and abuse [5].

The Great Ruaha River (GRR) arises in the highlands of the Usangu catchment, which is located in the rift valley in south-west Tanzania. Water drains off the highlands into the Ruaha National Park - through the Usangu Plains; into the Usangu Wetland; emptying at the northeastern extreme of the catchment at Ng'iriama, into the Middle GRR to the reservoir and power plants at Mtera and Kidatu, before joining the Rufiji River and emptying into the Indian Ocean (Figure 1).

The overall area of the Usangu Wetlands can be conveniently divided into two main portions, the Eastern Wetland and the Western Wetland (Figure 2). The core wetland, the Ihefu Swamp varies between 30 and $65 \mathrm{~km}^{2}$, whereas the seasonally wetted areas varies between 260 and $1800 \mathrm{~km}^{2}$. Drainage from the swamp is controlled by a rock bar at the downstream margin of the perennial 
swamp at N'Giriama, which acts like a natural dam with a fixed spillway. Overspill only flows to the Great Ruaha River when upstream water levels rise above the level of the rock bar. Although in each individual wetland there is a very complex network of channels and wetlands, at the connecting point between them, called Nyaluhanga, there is a construction where all the rivers are reduced to a single channel over a short distance of about $200 \mathrm{~m}$.

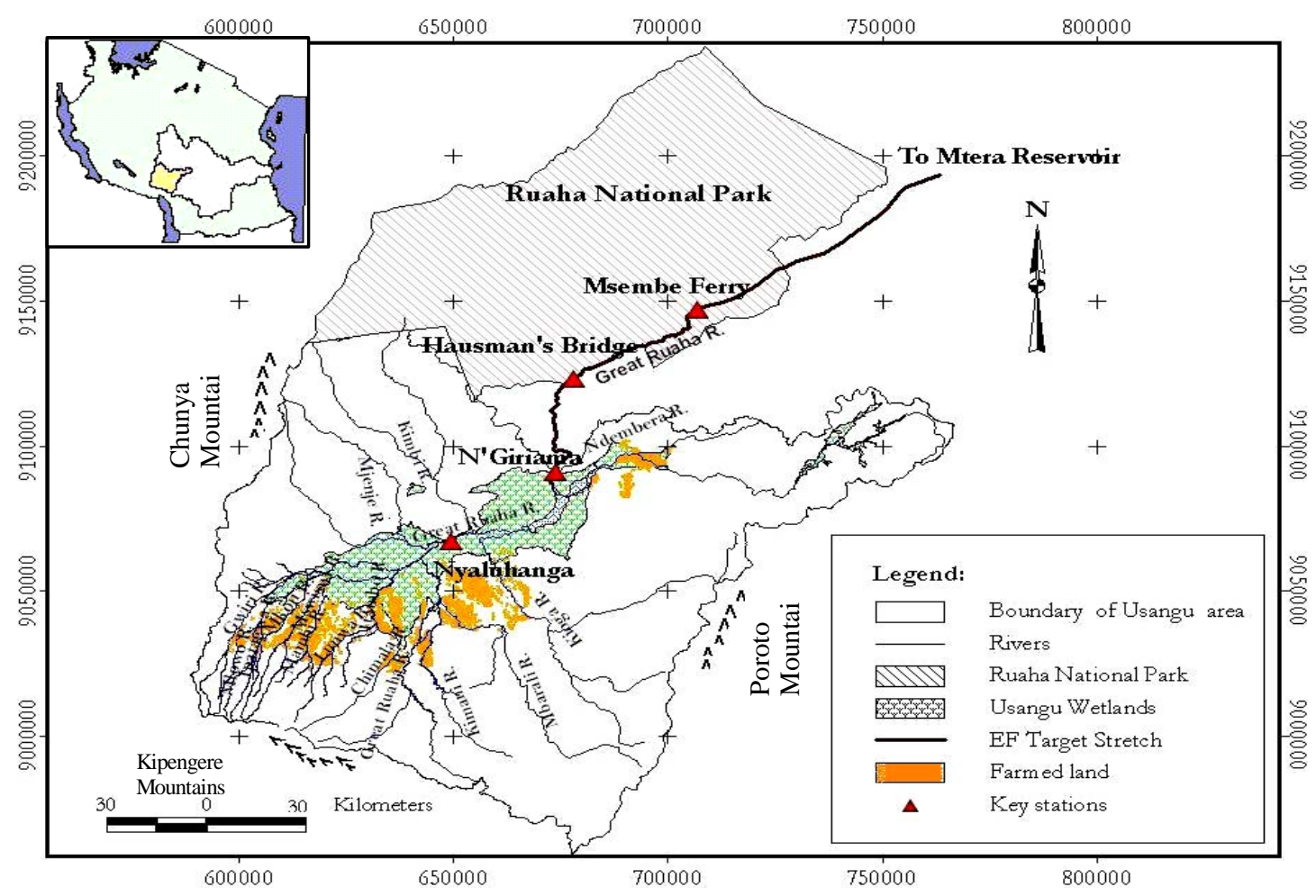

Figure 1. Map of usangu catchment showing irrigation schemes.

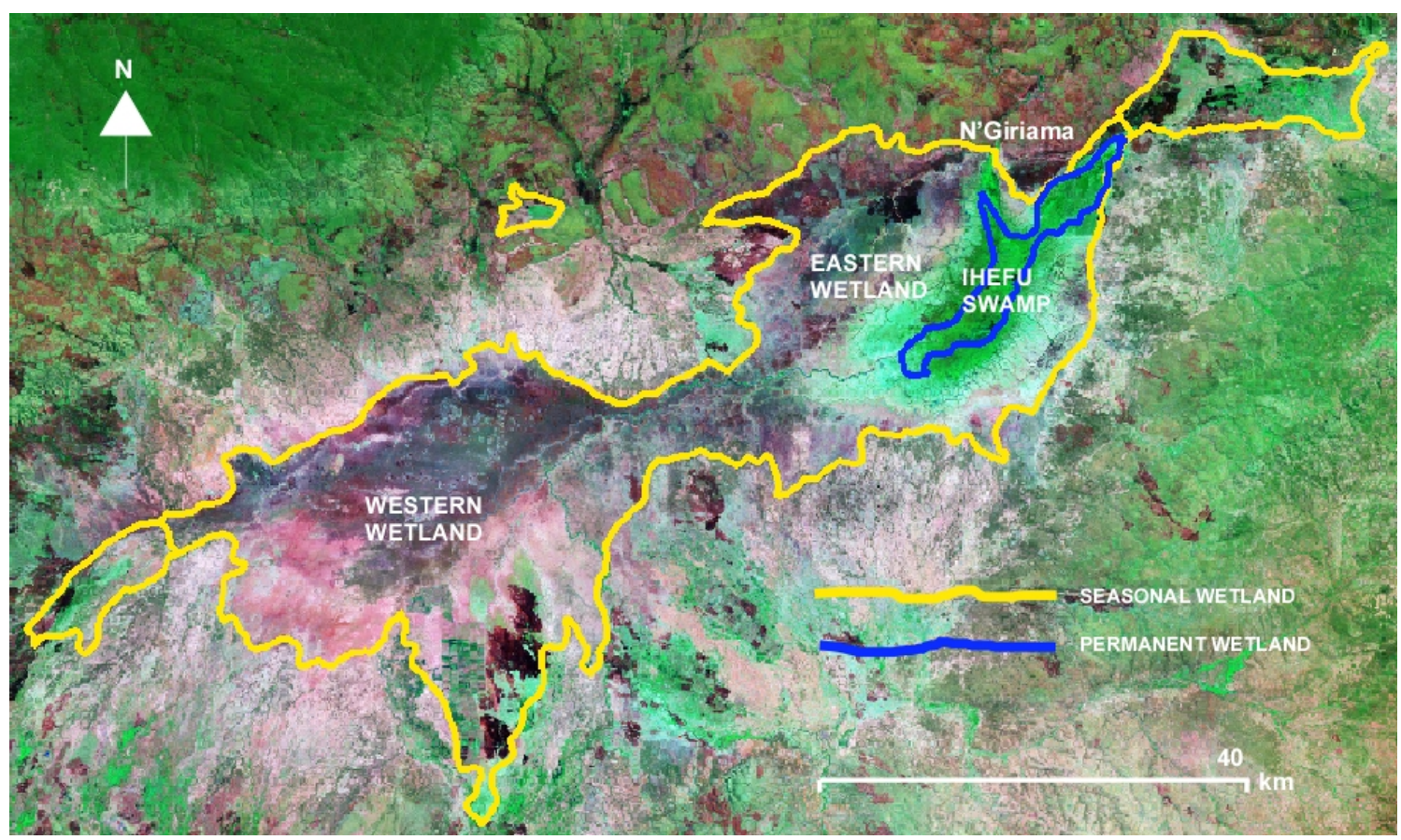

Figure 2. The Usangu wetlands (source: SMUWC, 2001). 
Although hydrologically linked, there are distinct differences between the western and eastern sub-basins. The western wetland is an irregular and somewhat imprecisely defined area crossed by a series of drainages emanating from the surrounding highlands. This wetland receives most of the inflow into the central plain; inflowing rivers here account for some $80 \%$ of total inflow.

The irrigated agriculture is most important as a user of water and impacts most heavily on Usangu wetlands. Abstraction of water for agriculture is leading to dried up rivers, falling ground water tables, salinated soil and polluted waterways [6].

Though, in an effort of meeting the government needs to address the Usangu wetland issues, a number of studies have been conducted on: water resources management [7-9]; irrigation and smallholder cultivators [10]; policy and institutional issues [11]; water and inter-sectoral issues [12]; and water and land uses [13,14], but there is an apparent knowledge gap on hydrologic conditions of Usangu wetlands. This paper addresses the current situation in the Usangu wetlands from hydrologic point of view. Several approaches were used in the collection of data for analysis. Both primary and secondary data was collected. Discussion with leaders was done prior to interview. This discussion was seen to be important to encourage their participation. Criterion for selection of representatives of villages had equal representation of village clusters, water user and gender. Key informants were selected based on the fact that they were knowledgeable on the issues of water management. Field survey was conducted on the Upper Great Ruaha River basin. The survey covered five rivers which are the source of water for irrigations on various schemes. The rivers include River Mlowo, Mambi, Lwanyo, Little Mkoji and Ipatagwa River. All these rivers feed their runoff to Mkoji River.

\section{Water Inflow to Ihefu Swamp and Vulnerability}

Four major perennial rivers feed the Ihefu swamp in Usangu wetlands. These include Kimani, Mbalali, Ndembera and the Great Ruaha River. As shown in Figure 3, in a dry season Mbalali River contributes between $69.17 \%$ to 47.78\%; Ndembera River contributes between $25 \%$ to 13.83\%; Kimani River contributes between 25\% to 8.33\% while Great Ruaha River contributes only $24.0 \%$ to $2.96 \%$. Great Ruaha River contributes the least compared to other rivers.

In terms of flow stability, Mbalali River shows constant stable inflow contributions to the Ihefu while Ndembera River indicates an increasing trend in contribution indicating a healthy environment of the Ihefu as related to these two rivers. However, Kimani and Great Ruaha River give a decreasing trend to the inflow. The range between the lowest and the highest percentage of contribution is big, with Great Ruaha River giving the smallest inflow almost throughout the period. Figure 4 below depicts the individual river inflows and the total inflow to the swamp.

River flow percentage contiribution to Ihefu swamp and trends

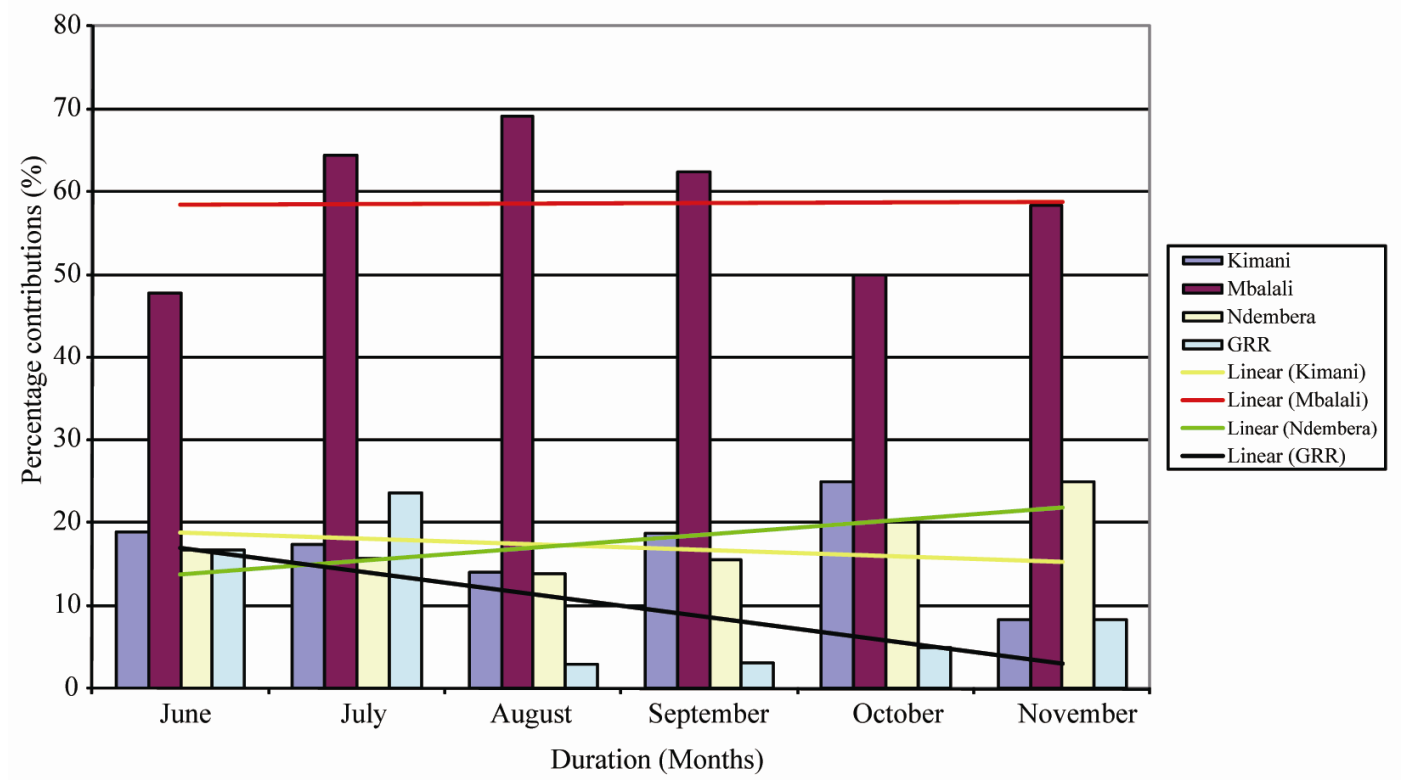

Figure 3. Inflow contribution to Ihefu swamp. 
River flows contribution to Ihefu swamp in dry season

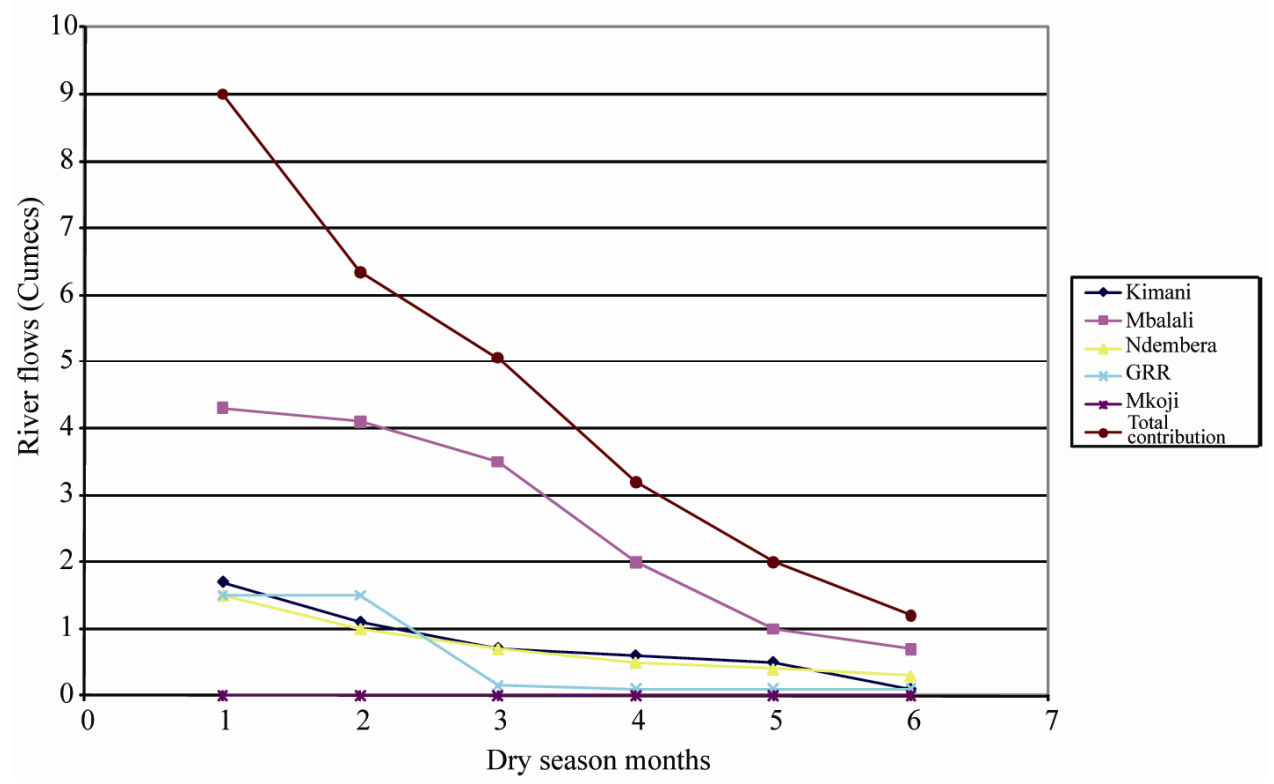

Figure 4. River flow towards the Ihefu swamp

Great Ruaha River which contributes the least amount of water towards the Ihefu its catchment area is 83,979 (ha)-gauging station 1KA8A. That of the Kimani is 44,800 (ha) and it is 136,000(ha) - station 1KA9A and 219,000 (ha) —station 1KA33A for Ndembera River and for Mbalali River is 160,000 (ha) and its station is 1KA11A. Under the assumption that Great Ruaha is supposed to contribute more than what is contributing, then it can be judged that the vulnerability of the Ihefu swamp in Usangu plains is due to the low flows of Kimani and Great Ruaha Rivers. These rivers deserve further investtigation to explore what makes them and the people that depend upon them vulnerable.

\section{Great Ruaha River and the Upper Catchments of the River}

Detailed investigation on water flows in the Great Ruaha River reveals that this river gets its flows from Great Ruaha and Mkoji sub-catchments. A number of rivers drain Mkoji sub-catchment are as shown in Figure 5. below. In this study water flow analysis is done only on Lunwa, Mlowo and Mswiswi Rivers which have operational gauging stations. These upstream rivers were selected so as to give the actual situation of what is happening on the upstream catchments of Great Ruaha River Basin.

Mswiswi River, Mlowo and Lunwa Rivers join together on the lower zone of the Mkoji catchment to form Mkoji River. All three rivers have variable flows as depicted on Figure 6 below. Figure 6 indicate a decreasing trend of flow on Mswiswi River. This trend was not expected to be so given that Mswiswi River gets its flow from other rivers on the upstream. This result shade a picture that, water from Mswiswi River is lost on its way to Mkoji River and that dependant of this river are vulnerable to water supply.

As depicted in Figure 7, since irrigation and land are related and interact dynamically, irrigation and farming are also seen to be the causative of dryness. Impliedly, both irrigation and farming in the basin are unplanned. In a similar manner, it is argued that grazing areas are also not planned and probably regulations formulated fall short of enforcement due to unplanned land use issue.

Table 1 shows crop water use during the dry season for middle and lower part of the Mkoji Sub catchment (MSC). There is no dry season crop in the lower part of the MSC because all the irrigation water from the rivers in the MSC is completely depleted within the middle part. The total area under dry season irrigation is 2772 ha. The area is distributed into 1775ha for the upper and 997ha for the middle parts of MSC. The total water use for dry season irrigation in the MSC is $10.86 \mathrm{Mm}^{3}$.

The study revealed that, between $30 \%$ and $60 \%$ of the water abstracted for irrigated agriculture is returned to rivers. In many instances this water is polluted with salts, fertilisers and pesticides and so is only of limited, if any, value to other sectors. Leaching of excess nutrients from farms into water sources causes eutrophication, which damages aquatic flora and fauna by producing algal blooms and depressing dissolved oxygen levels. Increased sediment loads in rivers arising from erosion of agricultural 
land have a negative impact on downstream aquatic ecosystems and also result in increased siltation in down- stream channels, reservoirs and other hydraulic infrastructure.

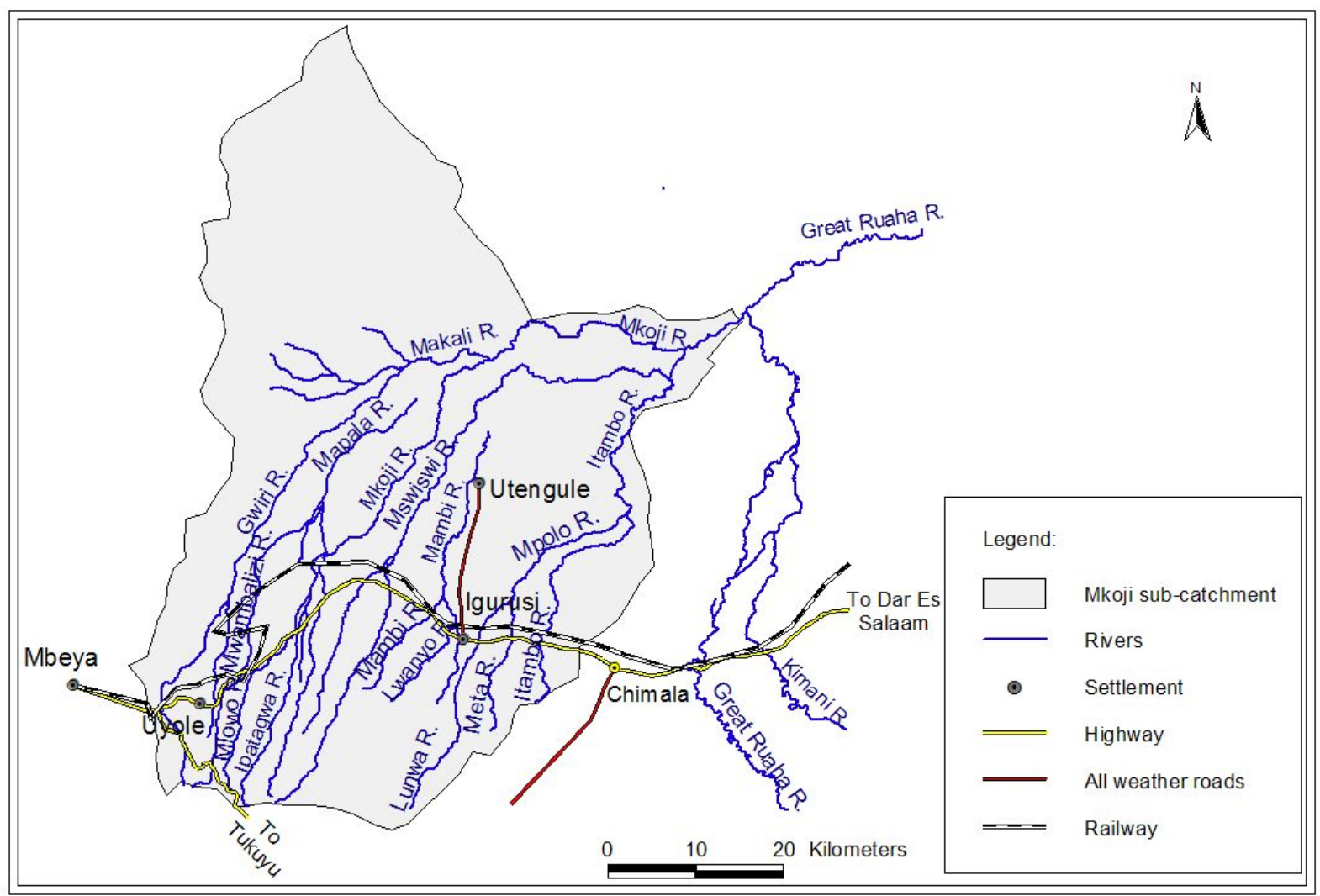

Figure 5. Rivers draining into Great Ruaha River before the Ihefu swamp.

Long term rivers flow

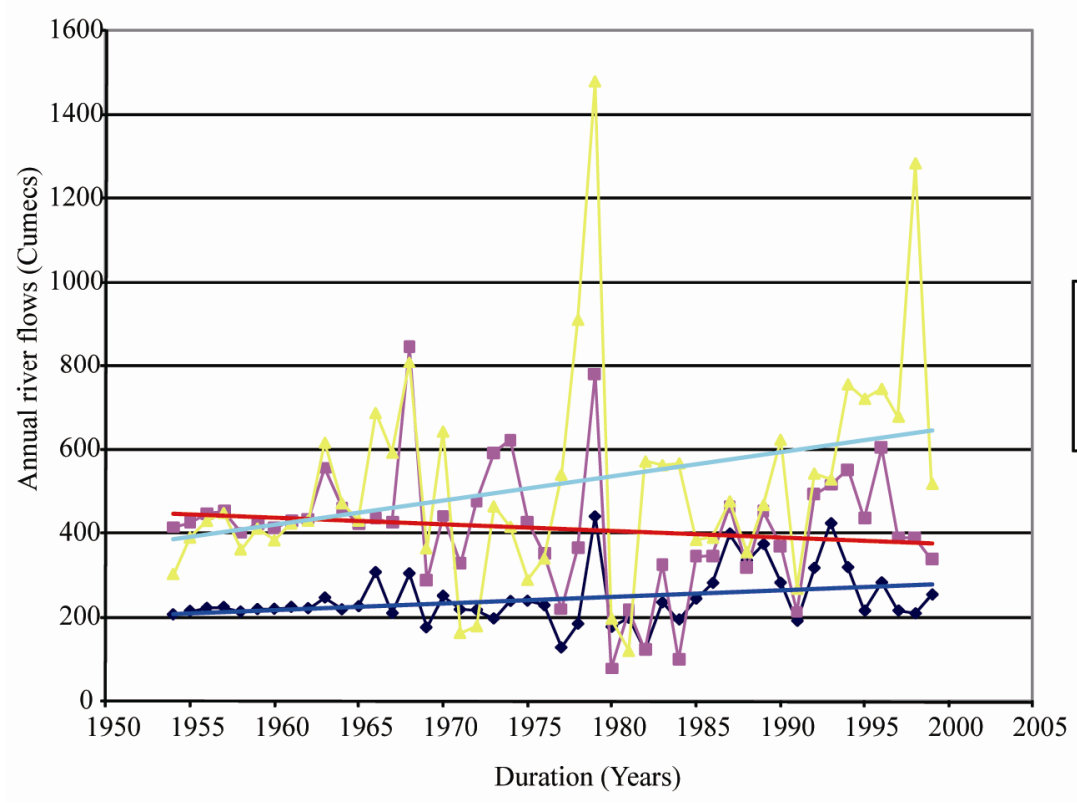

$\rightarrow-$ Mrombo River

- -Mswiswi River

4- Lunwa Rive

- Linear (Mrombo River

- Linear (Mswiswi River)

Linear (Lunwa River)

Figure 6. Long term flow of Lunwa Mlowo and Mswiswi Rivers. 


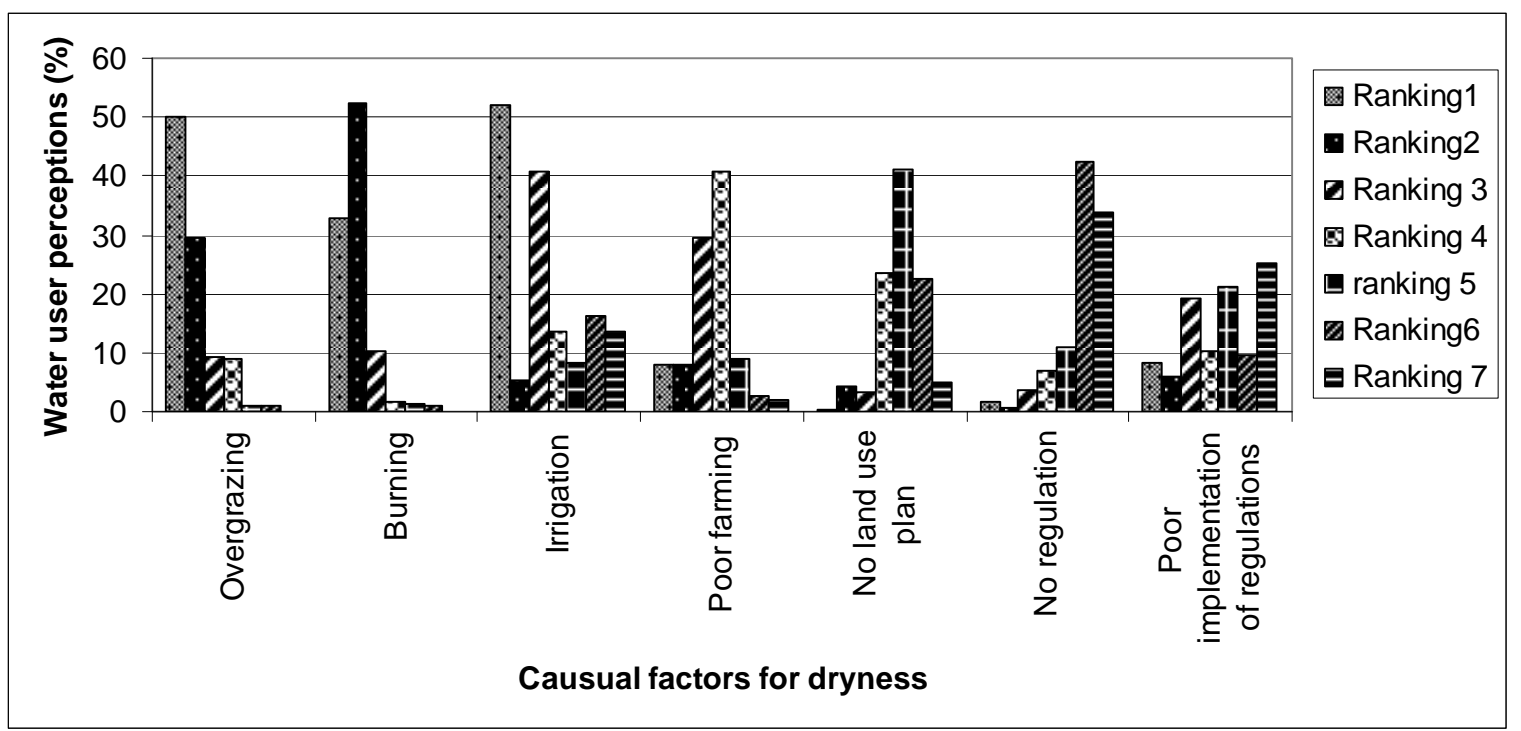

Figure 7. Factors affecting for Great Ruaha River.

Table 1. Crop water use under irrigation in upper and middle Mkoji Sub catchment.

\begin{tabular}{ccccccc}
\hline \multirow{2}{*}{ Crop } & \multicolumn{3}{c}{ Upper } & \multicolumn{3}{c}{ Middle } \\
\cline { 2 - 7 } & Total area (ha) & CWR (m) & Mm $^{3}$ & Total area (ha) & CWR (m) & Mm $^{3}$ \\
\hline Maize & 902 & 0.47 & 4.24 & 402 & 0.36 & 1.45 \\
Onions & 214 & 0.51 & 1.08 & 47 & 0.39 & 0.18 \\
Beans & 413 & 0.33 & 1.35 & 313 & 0.27 & 0.84 \\
Tomatoes & 245 & 0.33 & 0.81 & 235 & 0.39 & 0.92 \\
Total & $\mathbf{1 7 7 5}$ & $\mathbf{1 . 6 3}$ & $\mathbf{7 . 4 8}$ & $\mathbf{9 9 7}$ & $\mathbf{1 . 4 0}$ & $\mathbf{3 . 3 8}$ \\
\hline
\end{tabular}

\section{Conclusions}

This study has identified irrigation as the main reason of the reduced flows into the Usangu wetlands and eventually into the Great Ruaha River through the Eastern Wetland. The irrigated agriculture is most important as a user of water and impacts most heavily on wetlands. Abstraction of water for agriculture is leading to dried up rivers, falling ground water tables, salinated soil and polluted waterways. Water assigned for wetland protecttion is not available for other uses. In this sense the environment can be seen as a competitor by other users. It is true to say that a proportion of the total water available needs to be assigned to ecosystems, but the synergies with other uses can also boost the total resource by encouraging multiple use and reuse.

\section{Acknowledgements}

The author wish to acknowledge financial support received from REPOA-Tanzania. The author is grateful to
Mark Mwashihava for the valuable contribution on data collection.

\section{References}

[1] Kakakuona, "Wetlands Not Wastelands," Tanzania Wildlife Magazine, No. 21. April-June 2001, p. 68.

[2] K. de Voogt, G. Kite, P. Droogers and H. Murray-Rust, "Modeling Water Allocation between Wetlands and Irrigated Agriculture: Case Study of the Gediz Basin, Turkey," International Water Management Institute, Colombo, 2000.

[3] S. S. Mwakalila, "Opportunities and Challenges for Sustainable Water Resources Management in Tanzania," Geographical Journal, Vol. 174, No. 2, 2008, pp. 149-175. doi:10.1111/j.1475-4959.2008.00286.X

[4] L. J. Chapman, C. A. Chapman, P. J. Schofield, J. P. Olowo, L. Kaufman, O. Seehausen and R. Ogutu-Ohwayo, "Fish Faunal Resurgence in Lake Nabugabo, East Africa," The Journal of the Society for Conservation Biology, Vol. 17, No. 2, 2003, pp. 500-511. doi:10.1046/j.1523-1739.2003.01519.x 
[5] United Republic of Tanzania, "Sustainable Irrigation Management in Wetlands," Final Report, Ministry of Natural Resources and Tourism, Wetlands Unit, 2010.

[6] S. Mwakalila and N. Madulu, "Indigenous Knowledge and Institutional Setup in Wetlands Management in the Lake Victoria Basin, Tanzania,” OSSREA, Addis Ababa, 2009.

[7] S. S. Mwakalila, "Water Resource Use in the Great Ruaha Basin of Tanzania," Journal of Physics and Chemistry of the Earth, Vol. 30, No. 11-16, 2005, pp. 903-912.

[8] K. Rajabu, "Water Abstraction and Use Patterns and Their Implications on Downstream River Flows," Proceedings of the East Africa Integrated River Basin Management Conference, Sokoine University of Agriculture, Morogoro, 2005, pp. 233-232.

[9] SMUWC, "Sustainable Management of the Usangu Wetland and its Catchment," Final Report, United republic of Tanzania, 2001.

[10] B. Lankford, "Irrigation, livelihoods and River Basins," In: F. Ellis and H. Freeman, Eds., Rural Livelihoods and
Poverty Reduction Policies, London and Routledge, New York, 2005, pp. 274-293.

[11] C. S. Sokile, J. J. Kaishigili and R. M. Kadigi, "Towards an Integrated Water Resource Management in Tanzania: The Role of Appropriate Institutional Framework in Rufiji Basin,” Physics and Chemistry of the Earth, Vol. 28, No. 20-27, 2003, pp. 1015-1023.

[12] J. J. Kaishigili, M. J. Kadigi, C. S.Sokile and H. F. Mahoo, "Constraints and Potential for Efficient Inter-Sectoral Water Allocation in Tanzania,” Physics and Chemistry of the Earth, Vol. 28, No. 20-27, 2003, pp. 839-851.

[13] L. Moirana and C. L. Nahonyo "Why the Usangu Plains Should Be an Environmentally Protected Area (Usangu Game Reserve),” August 1996.

[14] I. S. Kikula, S. Charnley and P. Yanda, "Ecological changes in the Usangu Plains and Their Implications on the Downstream Flow of the Great Ruaha River in Tanzania," Research Report No. 99 (New Series), Institute of Resource Assessment, Dar es Salaam, 1996. 